\title{
木構造データに対するカーネル関数の設計と解析
}

\section{Design and Analysis of Convolution Kernels for Tree-Structured Data}

\author{
鹿島 久嗣日本アイ・ビー・エム株式会社 東京基礎研究所 \\ Hisashi Kashima Tokyo Research Laboratory, IBM Research \\ hkashima@jp.ibm.com \\ 坂本 比呂志
Hiroshi Sakamoto \\ 九州工業大学 知能情報工学科 \\ Department of Artificial Intelligence, Kyushu Institute of Technology \\ hiroshi@donald.ai.kyutech.ac.jp \\ $\underset{\text { 小eruo Koyanagi }}{\text { 小柳 }}$ \\ 日本アイ・ビー・エム株式会社 東京基礎研究所 \\ Tokyo Research Laboratory, IBM Research \\ teruok@jp.ibm.com
}

keywords: kernel methods, convolution kernels, tree kernels, support vector machines

\section{Summary}

We introduce a new convolution kernel for labeled ordered trees with arbitrary subgraph features, and an efficient algorithm for computing the kernel with the same time complexity as that of the parse tree kernel. The proposed kernel is extended to allow mutations of labels and structures without increasing the order of computation time. Moreover, as a limit of generalization of the tree kernels, we show a hardness result in computing kernels for unordered rooted labeled trees with arbitrary subgraph features.

\section{Introduction}

近年，予め特徵ベクトルで表現されたデータのみなら ず , 配列 , 木 , グラフなどの構造をもったデータを扱うよ うな学習の重要性か増している.たとえば, 自然言語処 理 [Manning 99] の分野において, テキストは配列として 表現され，また，構文解析されたテキストは構文解析木 として表現される.バイオインフォマティクス [Durbin 98]の分野においては, DNA , RNA , たんぱく質などの 配列データや，RNA の木構造データなどがある . 時に は,たんぱく質の3次元構造は, グラフデータとして表 現される.Web データの解析においては，ドキュメント は通常 XML や HTML などのいわゆる半構造データと 呼ばれる形式で記述され，また，Webサイト内での購買 履歴や, 行動履歴も配列や木, グラフ構造をもったデー タとして表現できる.さらに ,データ内の構造だけでは なく，データ間の構造も考えられる．たとえば，たんぱ く質や遺伝子のネットワーク，WWW のリンク構造など も，たんぱく質や遺伝子，ハイパーテキストなどの関係 を表す大きなグラフ構造として捉えることができる .

本論文で我々は，特に木構造をもつたデータを対象と する学習問題について考える，一般的な学習問題では， 対象となるデータは特徵空間中の 1 点 (ベクトル) として 与えられ, 例えば 2 值分類の問題であれば, 分類器の学 習は正例の点と負例の点を分類する超平面などのルール を学習することになる．しかしながら，特徵空間の定義
は予め与えられていることを前提として設計されており， 構造をもつたデータに対する一般的な特徵空間の定義は 自明ではない，構造を持ったデータを扱う方法として自 然である考えられる方法のひとつは , データに含まれる 部分構造を特徵として用いることであろう.この場合，例 えば, 特徵ベクトルのある次元の定義は, ある部分構造 か㳔象のデータに含まれるかどうかを表す 2 值 $(0 / 1)$ の 值，あるいは，含まれる回数などを用いることが考えら れる . 木構造データの場合には, 各特徵として用いる部 分構造は, 対象の木に含まれるパスや, 部分グラフとす るのが自然であろう．しかしながら全ての部分構造を考 えて，陽にベクトル表現をしてしまうと，たとえばある 木の中に含まれる部分グラフの数は, 木のサイズに関し て指数的に多くなりうるため, 計算コスト的な問題があ る. また，もうひとつの問題として，高次元のデータを 扱うことは，いわゆる「次元の呪い」と呼ばれる予測性 能の低下を引き起こすという問題がある . 従来は , この 問題に対して，なんらかの方法によって分類に有効な属 性のみを選ぶことで, 用いる属性の数を絞るということ がなされてきた .

一方，カーネル法 [Shawe-Taylor 04] と呼ばれる学習 器のクラスが近年注目を集めている.カーネル法の重要 な特徽の 1 つとして, カーネル関数を用いたデータアク セスが挙げられる . カーネル法は, データにアクセスす る際に, 単体ではなく, 必ず 2 つのデータの内積の形で アクセスする .これはすなわち, 特徵空間の次元がどん 
なに高くとも (たとえ，無限次元であろうとも)，なんら かの方法によって特徵べクトルの内積だけを高速に計算 することができるならば, 学習器の訓練にも予測にも特 徵空間の次元が明示的に現れることがないことを意味す る.この内積を与える関数は「カーネル関数」と呼ばれ， カーネル法はカーネル関数を用いることで, 高次元の特 徵空間においても効率的に働くことができる .さらに， カーネル法の代表的な手法であるサポートベクターマシ ン [Vapnik 95] においては, 次元に依存しない汎化性能 か理論的，実験的に示され，次元の呪いを克服できるこ とが確認されている.

カーネル関数の設計方法に関しては絶対的な指針は存 在しないが, Haussler は, 離散的な構造をカーネル法に よって扱うためのカーネル関数の一般的な枠組みとして 「畳み込みカーネル」を提案している [Haussler 99] . 畳 み込みカーネルの基本的な考え方は, 対象のデータは光 れに含まれる「パーツ」に分解され，カーネル関数は光 れらの間のカーネル関数の和によって定義される，とい うものである .この枠組みに従い, Collins らは自然言語 処理において現れる構文解析木に対する畳み込みカーネ ルを提案している [Collins 02] . 彼らは, 構文解析木を， 产の中に含まれる, ある種の部分グラフの出現回数を用 いて (非明示的な) ベクトル表現を行い, 効率的な内積の 計算方法を提案している．しかしながら，彼らの用いた 部分グラフは，あるノードの子ノードが順番によってラ ベル付けされており，しかも，彼らの提案した計算方法 は关の仮定に強く依存しているためより一般的なクラス の木には光のままでは適用できない .

乥こで, 一体どのくらい一般的な木に対して木カーネ ルを設計可能かという疑問が生ずる．この論文で我々は この問いに対してある程度答えることを目的とする . 次 に，我々はラベル付き順序木に対する，任意の部分グラ フを属性とするような木カーネルを効率的に計算できる アルゴリズムを示し, 弚の計算量は構文解析木カーネル と同等であることを示す．さらに，我々は提案したラべ ル付き順序木カーネルを計算量を増やすことなく，ラベ ルや, 構造の曖昧さを許すような柔軟性をもつように拡 張する . また , 一般化の限界として ，一般的なラベルつ き根付き木に対して，任意の部分グラフを属性とするよ うな木カーネルを計算することの計算困難性を示す .

乥して最後に，提案したカーネル関数か構造的な情報 を効果的に活用できていることを確認するために，人工 データと実際の HTML 文書を用いた簡単な実験を行う．

本論文の構成は以下の通りである. まず 2 章において， 曽み込みカーネル [Haussler 99] の考え方を述べ, 光の枠 組みに従って構文解析木カーネル [Collins 02] を紹介す る. 3 章では, より一般的な構造データであるラベル付 き順序木に対する畳み込みカーネルの提案と，产のいく つかの拡張を提案する. 4 章では, 最も一般的な木カー ネルを考えた場合の計算困難性を示す .5 章では提案し
たカーネル関数を用いた計算機実験の結果を示す. 6 章 では関連研究を紹介し， 7 章は結論とする。

\section{2. 畳み込みカーネルと木カーネル}

\section{$2 \cdot 1$ 畳み込みカーネル}

Haussler は, 構造をもったデータの特徵は, 兴の構造 に含まれる部分構造が担っていると考え, 構造データ同 士のカーネル関数を, 部分構造同士のカーネル関数によっ て再帰的に定義するという考え方に基づき，離散的な構 造に対するカーネル関数設計の一般的な枠組みとして畳 み込みカーネルを提案した [Haussler 99] . 畳み込みカー ネルは，2つの構造データ $T$ と $T^{\prime}$ が与えられたとき

$$
K\left(T, T^{\prime}\right)=\sum_{s \in S(T)} \sum_{s^{\prime} \in S\left(T^{\prime}\right)} K^{S}\left(s, s^{\prime}\right)
$$

と定義される.ここで $S(x)$ は $x$ から取り出される部分 構造の集合を表し, $K^{S}$ は2 2 つ部分構造の間に定義さ れるカーネル関数であるとする. 畳み込みカーネルは, $T$ と $T^{\prime}$ から部分集合 $S(T)$ と $S\left(T^{\prime}\right)$ を取り出し, 弚れらの 間のカーネル関数値をすべて足し合わせることで定義さ れる.つまり, 2 つのデータの類似度が, データの部分構 造の類似度に還元されるのである. 乥して, 部分構造の類 似度は，(1)によって更なる部分構造をもちいて再帰的 に定義されうる. $K^{S}$ がカーネル関数である場合に，(1) もカーネル関数となっていることが保証される.

ここで, $T$ と $T^{\prime}$ が共に木構造データ,すなわち $V$ と $V^{\prime}$ を頂点の集合， $E$ と $E^{\prime}$ を枝の集合として, $T=(V, E)$ と $T^{\prime}=\left(V^{\prime}, E^{\prime}\right)$ であるとき，(1) を木カーネルという . 木構造データのクラスや, 部分構造 $S$ のクラス, $K^{S}$ の 定義を変えることによって，樣々な木カーネルを定義す ることができる .

本論文では部分構造 $S$ の種類を最も一般的に，木に含 まれる全ての部分グラフの集合であると定義する . 木の 部分グラフは, 木構造であるため, (1) は以下のように 分解することができる .

$$
\begin{aligned}
K\left(T, T^{\prime}\right) & =\sum_{v \in V} \sum_{v^{\prime} \in V^{\prime}} \sum_{s \in S_{v}(T)} \sum_{s^{\prime} \in S_{v^{\prime}}\left(T^{\prime}\right)} K^{S}\left(s, s^{\prime}\right) \\
& =\sum_{v \in V} \sum_{v^{\prime} \in V^{\prime}} K^{R}\left(v, v^{\prime}\right)
\end{aligned}
$$

ここで, $S_{v}(T)$ は頂点 $v \in V$ を根として持つような木構 造をもつた部分グラフの集合とする .また,$K^{R}\left(v, v^{\prime}\right) を$ $S_{v}(T)$ と $S_{v^{\prime}}\left(T^{\prime}\right)$ に限定したときのカーネルで，

$$
K^{R}\left(v, v^{\prime}\right)=\sum_{s \in S_{v}(T)} \sum_{s^{\prime} \in S_{v^{\prime}}\left(T^{\prime}\right)} K^{S}\left(s, s^{\prime}\right)
$$

とする

\section{$2 \cdot 2$ 構文解析木カーネル}

Collins と Duffy は, 自然言語処理で用いられる構文解 析木(図 1 左)の間の畳み込みカーネルを設計した [Collins 
02] . 構文解析木は , ラベル付き順序木 , すなわち , 任意 の頂点について , アルファベット $\Sigma$ の内 1 つがラベルと して振られ，子供に全順序関係があるような , 根付き木 であるとみなせる.$S(T)$ としては,$T$ の部分グラフと して現れる全てのラベル付き順序木を用いる . 但し , 全 ての枝には炎の枝が親頂点の何番目の子に繋がる枝かを 表す番号でラベル付けされているとする (図 1 右) . また， 2 つの部分構造 $s \in S(T)$ と $s^{\prime} \in S\left(t^{\prime}\right)$ の間のカーネル関 数を

$$
K^{S}\left(s, s^{\prime}\right)=I\left(s=s^{\prime}\right)
$$

と定義する.ここで $I()$ は括弧内が成立する場合に 1 , 光 うでない場合に 0 となるような関数とする.また,$s=s^{\prime}$ は, 2 つのラベル付き順序木 $s$ と $s^{\prime}$ が枝のラベルも含め て完全に一致することを意味するとする .

(1) の計算を $S(T)$ と $S\left(T^{\prime}\right)$ を明示的に数え上げて計 算を行おうとすると, 兴の数は指数的に大きくなってし まうという問題がある. 弚こでCollins らは，(2)の分解 と, (3) が全ての $v$ と $v^{\prime}$ に対して以下の再帰式によって $O\left(|V|\left|V^{\prime}\right|\right)$ で再帰的に計算できることを利用して, 効率 的にカーネル計算を行う方法を示した。

• $v$ あるいは $v^{\prime}$ が葉のとき ,

$$
K^{R}\left(v, v^{\prime}\right)=I\left(\ell(v)=\ell\left(v^{\prime}\right)\right)
$$

• $v$ と $v^{\prime}$ が葉でないとき ,

$$
\begin{aligned}
K^{R}\left(v, v^{\prime}\right) & =I\left(\ell(v)=\ell\left(v^{\prime}\right)\right) \\
& \cdot \prod_{i=1}^{\sharp c h(v)}\left(K^{R}\left(\operatorname{ch}(v, i), \operatorname{ch}\left(v^{\prime}, i\right)\right)+1\right)
\end{aligned}
$$

ここで, 再帰式 (6) において $\sharp c h(v)$ は頂点 $v$ の子の数 を, $\operatorname{ch}(v, i)$ は $v$ の $i$ 番目の子頂点を表すとする.$v$ を根 にもつような木は，vの子を根に持つような木を組み合 わせて，炎の上に $v$ を付け加えることで構成できるため， $K^{R}\left(v, v^{\prime}\right)$ は， $v$ の子を根にもつような木と $v^{\prime}$ の子を根 に持つような木のカーネルの全ての組み合わせを列挙し ((6) の右辺 2 項目), 兴の上に $v$ と $v^{\prime}$ の頂点同士のカーネ ルを加える ((6) の右辺 1 項目) ことによって構成できる $v$ と $v^{\prime}$ のラベルが異なるときには, 両方を根に持つような 木構造部分グラフは当然存在しないため, $K^{R}\left(v, v^{\prime}\right)=0$ となる. また, (6) の右辺 2 項目において, 枝には炎の枝 が親頂点の何番目の子に繋がる枝かを表すラベルがつい ているため, $v$ の $i$ 番目の子を根に持つ木と $v^{\prime}$ の $i$ 番目 の子を根に持つ木のカーネルのみが考慮される .

\section{3. ラベル付き順序木カーネル}

\section{$3 \cdot 1$ ラベル付き順序木カーネル}

本節では, 前の章で紹介した構文解析木カーネルが仮 定している制約を取り除き，より一般的なラベル付き順 序木カーネルを提案する .

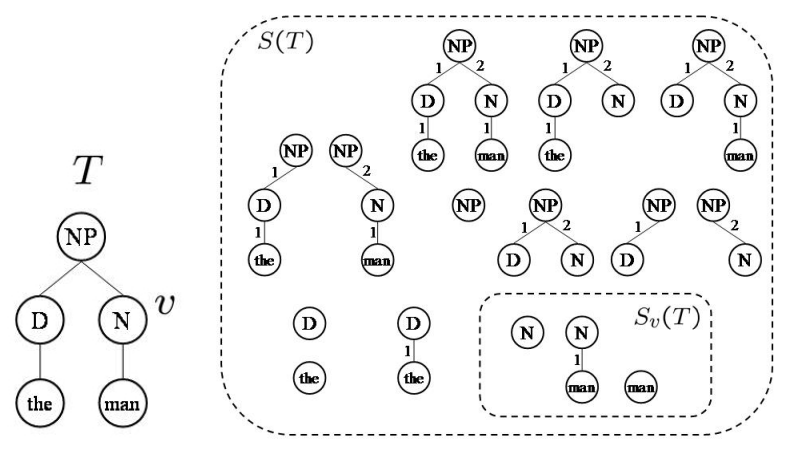

図 1 左: 構文解析木 $T$ の例 右: 構文解析木カーネルにおける部分構造 $S(T)$ と $S_{v}(T)$

構文解析木カーネルでは， $S(T)$ として，枝に子の位置 を示したラベルが振られているため，木の形が一致して も，子の位置を示すラベルが正確に一致しないと同じ部 分構造であるとみなされないという問題点がある．従っ て，例えば図 1 右における部分構造 $s$ は $N$ のラベルを持 つ頂点の下に $\operatorname{man}$ のラベルを持つ頂点が 2 番目の子と して付いているような構文解析木の分類には意味を成さ ない .この制約は, HTML 文書などのように，ひとつの 頂点が多数の子頂点をもちうる一般のラベル付き順序木 を考えた際には好ましくない，従って，我々はこの制約 を取り除き， $S(T)$ として， $T$ の部分グラフとして現れ る全てのラベル付き順序木 (図 1 右で, 子の位置を示す ラベルを取り除いたもの) を用いる．また，2つの部分構 造同士のカーネル (4) において,$s=s^{\prime}$ は, 2 つのラベ ル付き順序木が完全に一致することを意味するとする．

辺についている子の位置を示すラベルを取り除いたこ とにより，(6) の右辺 2 項目において，必ずしも $v$ の $i$ 番目の子を根とする木と $v^{\prime}$ の $i$ 番目の子を根とする木 のカーネルのみだけでなく，すべての $i$ と $j$ の組につい て考慮する必要がある.従って,$v$ と $v^{\prime}$ の子頂点を根と するようなカーネルの組み合わせは，子供の順序を保存 した，あらゆる組み合わせを考慮する必要がある．しか しながら, $v$ と $v^{\prime}$ の子供の部分集合の選び方は光れ光れ $2^{\sharp c h(v)}$ 個と $2^{\sharp c h\left(v^{\prime}\right)}$ 個 , すなわちこれらの間のマッチン グの数は, 子の数に関して指数個存在するため, これを ナイーブに評価するのは困難である，乥こで，頂点同士 の動的計画法に加え，さらに内側のループとして，子供 同士の動的計画法を用いることにより，これを効率的に 行う方法を示す . $\bar{K}_{v, v^{\prime}}^{R}(i, j)$ を, (6) の右辺 2 項目に対応 する值で, $v$ の 1 番目の子から $i$ 番目の子まで，また , $v^{\prime}$ の 1 番目の子から $j$ 番目の子までに限定した場合のもの とする.すなわち，(6)のかわりに，

$$
K^{R}\left(v, v^{\prime}\right)=I\left(\ell(v)=\ell\left(v^{\prime}\right)\right) \cdot \bar{K}_{v, v^{\prime}}^{R}\left(\sharp \operatorname{ch}(v), \sharp \operatorname{ch}\left(v^{\prime}\right)\right)(7)
$$

とする . このとき, 以下の再帰式

$$
\begin{aligned}
& \bar{K}_{v, v^{\prime}}^{R}(i, j)=\bar{K}_{v, v^{\prime}}^{R}(i-1, j)+\bar{K}_{v, v^{\prime}}^{R}(i, j-1) \\
& \quad-\bar{K}_{v, v^{\prime}}^{R}(i-1, j-1)
\end{aligned}
$$




$$
+\bar{K}_{v, v^{\prime}}^{R}(i-1, j-1) \cdot K^{R}\left(\operatorname{ch}(v, i), \operatorname{ch}\left(v^{\prime}, j\right)\right)
$$

が成立する .ここで，境界条件 $\bar{K}_{v, v^{\prime}}^{R}(i, 0)=\bar{K}_{v, v^{\prime}}^{R}(0, j)=$ 1 とする .この再帰式 (8) は次のように説明できる . ま ず, 1 行目と 2 行目は, $v$ $v$ 番目の子と, $v^{\prime}$ の $j$ 番目 の子を用いない全てのマッチングを考慮する．2 行目で は, 1 行目で 2 回考慮している重なり部分を取り除いて いる. 3 行目では $v$ の $i$ 番目の子と, $v^{\prime}$ の $j$ 番目の子を 必ず用いるマッチングを考慮している．これは, 既に計 算している $1 \sim i-1$ 番目の子集合と $1 \sim j-1$ 番目の子 集合の間のマッチングに, $i$ 番目の子と $j$ 番目の子を加 えることで計算できる.この再帰式によって， $K^{R}\left(v, v^{\prime}\right)$ を $O\left(\sharp c h(v) \sharp c h\left(v^{\prime}\right)\right)$ て計算可能となる.

カーネル関数全体としての計算量は以下のように， $O\left(|V|\left|V^{\prime}\right|\right)$ となることがわかる.これは,構文解析木カー ネルと同じ計算量である .

$$
\begin{aligned}
& \sum_{v \in V} \sum_{v^{\prime} \in V^{\prime}} O\left(\sharp c h(v) \cdot \sharp c h\left(v^{\prime}\right)\right) \\
= & \sum_{v \in V} O(\sharp c h(v)) \cdot \sum_{v^{\prime} \in V^{\prime}} O\left(\sharp c h\left(v^{\prime}\right)\right) \\
= & O\left(|V| \cdot\left|V^{\prime}\right|\right)
\end{aligned}
$$

\section{$3 \cdot 2$ ラベル付き順序木カーネルの拡張}

前節て提案したラベル付き順序木カーネルでは, 2 つの 部分グラフ $s \in S(T)$ と $s^{\prime} \in S\left(T^{\prime}\right)$ 同士のカーネル関数 は, $s$ と $s^{\prime}$ がラベルも含めて完全に一致したときのみ值 1 をとるとした . しかしながら , 完全には一致しなくて も，形やラベルか似ているようなものについては，ある 程度一致すると判断したいような場合が考えられる . こ の節では, ラベルつき順序木カーネルにこのような柔軟 性を導入するための 2 つの拡張を考える .

まずは, ラベルについての柔軟性の導入を考える.形が まったく同一である $2 つ$ 部分グラフ $s$ と $s^{\prime}$ の間のカー ネルを，頂点ラベル間のカーネルの積と定義する．言い 換えると, $s$ に含まれる頂点を前順で並べた全順序集合を $V_{s}=\left(v_{1}, v_{2}, \ldots\right)$ とすると,

$$
K^{S}\left(s, s^{\prime}\right)=\prod_{i=1}^{\left|V_{s}\right|} K^{\Sigma}\left(\ell\left(v_{i}\right), \ell\left(v_{i}^{\prime}\right)\right)
$$

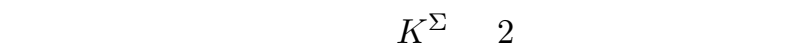
カーネル関数とする. $K^{\Sigma}\left(\sigma, \sigma^{\prime}\right)=I\left(\sigma=\sigma^{\prime}\right)$ としたとき に，もともとのラベルつき順序木カーネルに一致する . 従って, 以上のような変更を加えた場合でも，(7)を $K^{R}\left(v, v^{\prime}\right)=K^{\Sigma}\left(\ell(v), \ell\left(v^{\prime}\right)\right) \cdot \bar{K}_{v, v^{\prime}}^{R}\left(\sharp \operatorname{ch}(v), \sharp \operatorname{ch}\left(v^{\prime}\right)\right)$

のように置き換えればよい .

次に, 形に関しての柔軟性を導入する.ここでは, 部分 構造の集合 $S(T)$ の定義として，任意の頂点集合からな る部分構造を取り出すことができるように拡張する。た

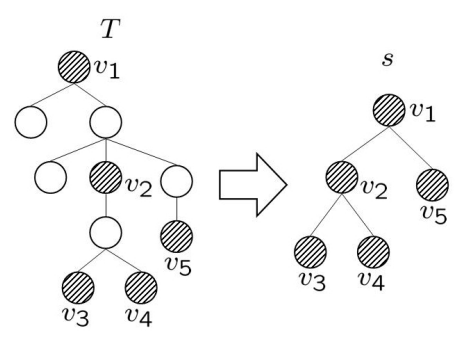

図 2 形に関する柔軟性を導入したときの, ラベル付き順序木 $T$ から取り出される部分構造 $s$ の例 .

だし, 取り出される木構造としては, 頂点間の相対位置, すなわち先祖・子孫の関係が保存されたような形で取り 出されるとする . 图 2 に, $T$ から $v_{1}, \ldots, v_{5}$ の 5 つの頂 点からなる部分構造 $s$ を取り出す例を示す. 頂点間の先 祖・子孫の関係が保存されていることに注意する.これ によって，構造の摇らぎに対して柔軟な特徽定義が実現 されることが期待できる .

このような拡張を行った場合のカーネルの効率的な計 算は, 基本的なアルゴリズムに変更を加えることで害現 できる.基本的なアルゴリズムにおける再帰式 (8)や (6) では, ある頂点 $v$ を根にもつような部分構造 $S_{v}(T)$ の集 合は, $v$ の頂点を根に持つような部分構造を組み合わ せて，vを追加することによって再帰的に構成できるこ とを利用していた 、しかしながら, 柔軟な部分構造取り 出しを許すことによって $v$ の子孫となる頂点を根に持つ ような部分構造までも考慮しなければならない . $v$ およ び $v$ の子孫の頂点を含むような集合を $D(v)$ とすると， $v$ 以下に含まれる部分構造の集合は

$$
S_{v}^{D}(T)=\bigcup_{u \in D(v)} S_{u}(T)
$$

と表される.ここで, $S_{u}(T)$ も「uを根にもつ任意の頂 点集合からなる部分構造の集合」というように, 定義が 拡張されていることに注意する.これを用いて，vと $v^{\prime}$ 以下の部分構造を用いたカーネル関数を

$$
K^{D}\left(v, v^{\prime}\right)=\sum_{s \in S_{v}^{D}(T)} \sum_{s^{\prime} \in S_{v^{\prime}}^{D}\left(T^{\prime}\right)} K^{S}\left(s, s^{\prime}\right)
$$

とおけば , (8) は

$$
\begin{aligned}
& \bar{K}_{v, v^{\prime}}^{R}(i, j)=\bar{K}_{v, v^{\prime}}^{R}(i-1, j)+\bar{K}_{v, v^{\prime}}^{R}(i, j-1)(10) \\
& \quad-\bar{K}_{v, v^{\prime}}^{R}(i-1, j-1) \\
& \quad+\bar{K}_{v, v^{\prime}}^{R}(i-1, j-1) \cdot K^{D}\left(\operatorname{ch}(v, i), \operatorname{ch}\left(v^{\prime}, j\right)\right)
\end{aligned}
$$

のように書き換えることができる .ここで $K^{D}\left(v, v^{\prime}\right)$ の計 算を $(9)$ の定義どおりに行うと, $O\left(\left|S_{v}^{D}(T)\right| \cdot\left|S_{v^{\prime}}^{D}\left(T^{\prime}\right)\right|\right)$ であるため, 全体として $O\left(|V|^{2} \cdot\left|V^{\prime}\right|^{2}\right)$ になってしまう が , これも以下の再帰式によって, $O\left(\sharp c h(v) \cdot \sharp c h\left(v^{\prime}\right)\right) て ゙$ 計算することができる .

$$
K^{D}\left(v, v^{\prime}\right)
$$




$$
\begin{aligned}
= & \sum_{i=1}^{\sharp \operatorname{ch}(v)} K^{D}\left(\operatorname{ch}(v, i), v^{\prime}\right)+\sum_{j=1}^{\sharp \operatorname{ch}\left(v^{\prime}\right)} K^{D}\left(v, \operatorname{ch}\left(v^{\prime}, j\right)\right) \\
& -\sum_{i=1}^{\sharp c h(v)} \sum_{j=1}^{\sharp c h\left(v^{\prime}\right)} K^{D}\left(\operatorname{ch}(v, i), \operatorname{ch}\left(v^{\prime}, j\right)\right)+K^{R}\left(v, v^{\prime}\right)
\end{aligned}
$$

\section{4. 木カーネル計算の困難性}

この章では, 前章で提案した木カーネルをさらに一般 化することが可能かという問題を考える .ラベル付き順 序木よりも一般的な木構造データとしては, 子頂点に順 序がないようなラベルつき根付き木が考えられる . 後に 示すように，ラベルつき根付き木に対する木カーネルを 定義した場合, ラベル付き順序木と同樣に任意の部分グラ フを部分構造として使用する場合には\#P-完全問題 , す なわちこれ以上の一般化は望めないことがわかる.

ラベル付き根付き木に対するカーネル関数を計算する 問題として，次の問題 TREE KERNEL を定義する.

\section{問題 1: TREE KERNEL $\left(T, T^{\prime}\right)$}

入力: ラベル付き根付き木 $T, T^{\prime}$

出力: $K\left(T, T^{\prime}\right)$

なお，一般性を失うことなく，常に $|V| \leq\left|V^{\prime}\right|$ であると 仮定する . また , 部分構造の集合 $S(T)$ は $T$ の全ての部分 グラフの集合とし, 部分構造同士のカーネル $K^{S}\left(s, s^{\prime}\right)=$ $I\left(s=s^{\prime}\right)$ とする .このため, $K\left(T, T^{\prime}\right)$ は $T$ と $T^{\prime}$ の共有 する部分グラフの個数を数え上げる問題に等しくなる. た だしこの場合，子頂点に順序がないため，構造の同一性 の判定には，子の順序の入れ換えが許されることに注意 する .

問題 1 の計算困難性を示すにあたり，まずは次の，限定 された部分構造に対するカーネル計算の問題を考える.

\section{問題 2: TREE KERNEL ${ }^{(n)}\left(T, T^{\prime}\right)$}

入力: ラベル付き根付き木 $T, T^{\prime}$

出力: $K^{(n)}\left(T, T^{\prime}\right)$

ただし, ここで $K^{(n)}\left(T, T^{\prime}\right)$ とは, $T$ の部分構造を $T$ の 「大きさがちょうど $n$ の」部分グラフに限定した場合の 集合 $S^{(n)}(T)$ とした場合の木カーネル

$$
K^{(n)}\left(T, T^{\prime}\right)=\sum_{s \in S^{(n)}(T)} \sum_{s^{\prime} \in S^{(n)}\left(T^{\prime}\right)} K^{S}\left(s, s^{\prime}\right)
$$

と定義されるとする. ここで, 特に $n=|V|$ の場合には, $S^{(|V|)}(T)=\{T\}$ となるため, $K^{(|V|)}\left(T, T^{\prime}\right)$ は, $T$ が $T^{\prime}$ 内に出現する (埋め込まれる) 回数を数えているのと等 価となることに注意する . また, $K^{(n)}\left(T, T^{\prime}\right)$ は $T$ と $T^{\prime}$ の共有する, 大きさがちょうど $n$ の部分グラフの個数を 数え上げるのに等しくなる.

このとき, TREE KERNEL ${ }^{(|V|)}\left(T, T^{\prime}\right)$ の計算困難性 を示す次の補題が成立する.

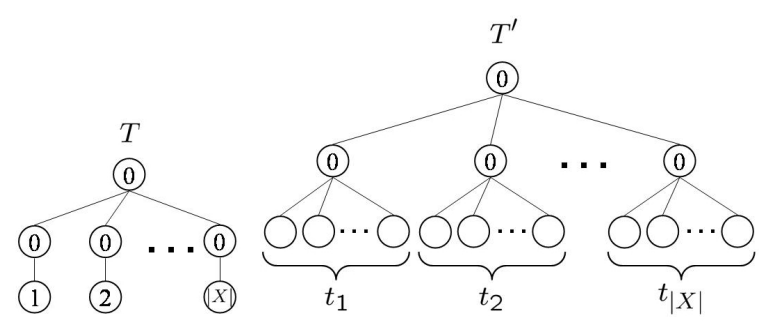

図 3 補題 1 の証明で用いる $T$ と $T^{\prime}$

補題 1:
TREE KERNEL ${ }^{(|V|)}\left(T, T^{\prime}\right)$ は \#P-完全である.

（ 証明）次の 2 部グラフ $G=(X \cup Y, E)$ に関する問題の 計算困難性をもとに，補題 1 を示すことにする．

問題 2: \#PERFECT MATCHINGS $(G)$

[Vadhan 01, Valiant 79b]

入カ: 2 部グラフ $G=(X \cup Y, E)$,ただし $|X|=|Y|$

出力: $G$ の完全マッチングの総数

ここで $X$ の頂点間， $Y$ の頂点間には光れ艺れ辺は存在 しないことに注意する.グラフ $G$ において , 辺のある部 分集合 $M \subseteq E$ に対して,$M$ のどの 2 つの辺も頂点を 共有しないとき, $M$ を $G$ のマッチングといい,$M$ が $V$ の全ての頂点を含むとき，これを完全マッチングという . \#PERFECT MATCHINGS $(G)$ は \# $P$-完全であるこ とが知られている.

ラベルの集合を $\Sigma=\{0,1,2, \ldots,|X|\}$ とし， $G$ に対し， 图のような $T$ と $T^{\prime}$ を考えることにする .ここで, 頂点 集合 $t_{j}$ は,$\Gamma\left(x_{i}, y_{j}\right) \in E$ であるならば，ラベル $i$ をつ 頂点が $t_{j}$ に含まれる」という規則によって決まるとする .

$G$ に辺 $\left(x_{i}, y_{j}\right) \in E$ が存在するときのみ , ラベル $i$ を もつ頂点が $t_{j}$ に含まれるため, このときに限り,$T$ のラ ベル $i$ を持つ頂点を $t_{j}$ に埋め込むことができる. $T$ が $T^{\prime}$ 内に出現するとき, 葉以外の部分は完全に一致するので， $T$ の葉が $t_{1}, \ldots, t_{|X|}$ に光れ光れ 1 回づつ埋め込まれるこ

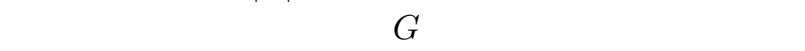
対応している.よって，TREE KERNEL ${ }^{(|V|)}\left(T, T^{\prime}\right)$ の 出力と \#PERFECT MATCHINGS $(G)$ の出力は等しく なるため, \#PERFECT MATCHINGS $(G)$ から多項式 時間でTREE KERNEL ${ }^{(|V|)}\left(T, T^{\prime}\right)$ に還元できること が示された .

以上に示した補題 1 を用いて, TREE $\operatorname{KERNEL}\left(T, T^{\prime}\right)$ についての計算困難性を示す以下の定理を証明できる .

\section{定理 1:}

TREE KERNEL $\left(T, T^{\prime}\right)$ は \#P-完全である .

（証明）Cook の還元 [Valiant 79a]，すなわち TREE $\operatorname{KERNEL}^{(|V|)}\left(T, T^{\prime}\right)$ が TREE KERNEL $\left(T, T^{\prime}\right)$ を解 くオラクルを用いて多項式時間て解けることを示すことで, TREE KERNEL $\left(T, T^{\prime}\right)$ は TREE KERNEL ${ }^{(|V|)}\left(T, T^{\prime}\right)$ 


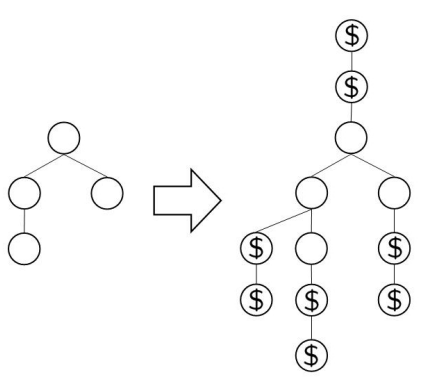

図 4 定理 1 の証明で用いる $T$ の変換 $(m=2$ の場合)

と同樣に難しいことを示す.

具体的には, TREE KERNEL ${ }^{(|V|)}\left(T, T^{\prime}\right)$ を, [Vadhan 01] のテクニックを援用し, 多項式時間て解ける連立一次 方程式に帰着する.

$\Sigma に$ に含まれない記号 $\$$ を導入し,$\Sigma^{\prime}=\Sigma \cup\{\$\}$ とする． 与えられた $T$ を, 以下の手順で $\Sigma^{\prime}$ 上の木に拡張する .

(1) 任意の $m=0, \ldots,|V|$ に対して, 長さ $m$ の鎖 $v_{1}-$ $v_{2}-\cdots-v_{m}$ をつくり, 鎖のすべての頂点にラベル \$をつける.

(2) Tのすべての頂点に1つずつこの鎖を接続する .

(3) このようにしてできた木を $T_{m}$ とする (図 4) .

同樣にして $T^{\prime}$ からも $T_{m}{ }^{\prime}$ に変換する.

以下では,こうして得られた $T_{m}$ と $T_{m}{ }^{\prime}$ に対して, TREE $\operatorname{KERNEL}\left(T_{m}, T_{m}{ }^{\prime}\right)$ の解を多項式時間て計算するオラク ルが存在すると仮定すると，TREE KERNEL ${ }^{(|V|)}\left(T, T^{\prime}\right)$ が多項式時間で計算できることを示す．

さて, 前述したように, $K\left(T_{m}, T_{m}{ }^{\prime}\right)$ は, $T_{m}$ と $T_{m}{ }^{\prime}$ の 共有する部分グラフの数に等しいが, これらの部分グラ フは, 以下の 3 つのクラスに分類することができる .
(a) \$のみを含むもの，
(b) \$を含まないもの，
(c) 両方を少なくとも1つずつ含むもの.

このうち (a)の形の共通部分グラフの出現回数を $A^{(0)}$ とおく .これは以下のように簡単に計算できる.

$$
\begin{aligned}
A^{(0)} & =|V|\left|V^{\prime}\right| \sum_{k=1}^{m}(m-k+1)^{2} \\
& =|V|\left|V^{\prime}\right| m(m+1)(2 m+1) / 6
\end{aligned}
$$

また, (b) の形の共通部分グラフのうち, 頂点数が $1 \leq$ $n \leq|V|$ であるものの数を $A^{(n)}$ とする . 同樣に, (c) の形 の部分グラフのうち，\$でない頂点数が $1 \leq n \leq|V|$ で あるものの数を $\tilde{A}^{(n)}$ とする.このとき, (c) に属する部 分グラフから $\$$ の頂点を取り去ったものと同型なものが (b) の中に存在する . また , $\$$ は $T, T^{\prime}$ には存在しないの で, $\tilde{A}^{(n)}$ と $A^{(n)}$ の違いは, 付け加えた長さ $m$ の鎖の部 分のみに依存する . (b) に属する, 大きさ $n$ のある部分グ ラフに注目したとき, 各頂点に $m$ 以下の長さの鎖を連結 したものが, (c) に属するはずであるので, (c)の中には, \$ の頂点を取り去ることでもとの部分グラフと同型になる
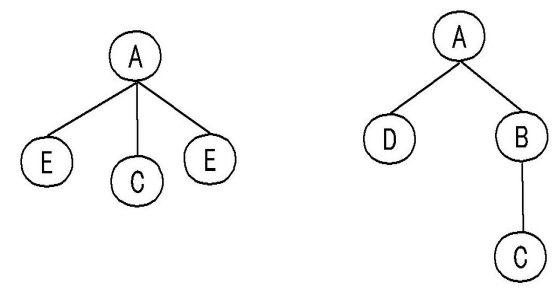

図 5 人エデータを用いた分類実験において正例に含まれる $2 つ$ の部分構造

ものが, $m^{n}$ 個あるはずである. 従って, $\tilde{A}^{(n)}=m^{n} A^{(n)}$ の関係が成立する.

以上により, $K\left(T_{m}, T_{m}{ }^{\prime}\right)$, すなわち $T_{m}$ と $T_{m}{ }^{\prime}$ の共有 する部分グラフの数は, 以下の式で表現できる.

$$
\begin{aligned}
K\left(T_{m}, T_{m}{ }^{\prime}\right) & =A^{(0)}+\sum_{n=1}^{|V|}\left(A^{(n)}+\tilde{A}^{(n)}\right) \\
& =A^{(0)}+\sum_{n=1}^{|V|}\left(1+m^{n}\right) A^{(n)} .
\end{aligned}
$$

ここで仮定より， $K\left(T_{m}, T_{m}{ }^{\prime}\right)$ は多項式時間で計算可能 であるので, この式は, $|V|$ 変数の連立1次方程式であり， $m=1, \ldots,|V|$ とすることにより, 異なる $|V|$ 個の式を得 ることができる.この連立方程式を解くことで任意の $A^{(n)}$ を決定できる.一方, $A^{(|V|)}$ はTREE KERNEL ${ }^{(|V|)}\left(T, T^{\prime}\right)$ の解であるため, TREE KERNEL ${ }^{(|V|)}\left(T, T^{\prime}\right)$ が多項式 時間て計算可能になる. 以上により, TREE $\operatorname{KERNEL}\left(T, T^{\prime}\right)$ は\#P-完全である .

\section{5. 実 験}

この章では，人エデータと実際の HTML データの両 方に対する分類問題において，提案手法か構造情報を有 効活用できているかどうかを検証する . カーネル学習器 としては, 実装の簡便さから, SVM と比較しても遜色 ない性能をもつカーネルパーセプトロン [Freund 99]を 用いた . カーネル関数としては, 提案したラベル付き順 序木カーネルの, 基本的なバージョン，および，構造の 柔軟性を許したバージョンを用い, ラベルの柔軟性は考 慮しなかった . 精度は, 全て leave-one-out のクロスバ リデーションによって計測を行った .

\section{$5 \cdot 1$ 人エデータを用いた分類実験}

まずは，人工的に生成したデータを用いた分類タスク における実験を行う．ここで, 人工データは部分構造を 認識しないと分類できないようなデータを生成し，これ を用いた . 具体的には, 図 5 に示すような 2 つの木構造 を両方とも部分グラフとして持っている場合に正例, 光 うでない場合には負例となるようなデータを生成した． 我々は, 弚れ光れ 30 個から 50 個のノードと, 10 種類の 
表 1 人エデータを用いた分類実験の結果 (leave-one-out クロス バリデーションによって計測 . 5 回の平均 .)

\begin{tabular}{ccc}
\hline$d$ & BoL カーネル & 木カーネル \\
\hline 1 & $\mathbf{5 7 . 8 \%}$ & $80.5 \%$ \\
2 & $55.6 \%$ & $\mathbf{8 4 . 4 \%}$ \\
3 & $56.7 \%$ & $80.6 \%$ \\
4 & $\mathbf{5 7 . 8 \%}$ & $76.1 \%$ \\
5 & $55.0 \%$ & $76.1 \%$ \\
\hline
\end{tabular}

ラベルを持つようなラベル付き順序木を，正例として 30 個 , 負例として 30 個のデータをランダムに生成した*1． カーネル関数としては, 基本のラベル付き順序木カー ネルと, 比較対照として, 'bag of labels (BoL)' カーネ ル，すなわち，サイズ1の木 (すなわち単一ノード) の みを部分構造とするようなカーネルを用いた . BoL カー ネルは木の構造についての情報をまったく用いないため， これを評価のベースラインとして用いた .

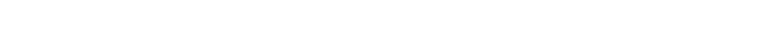
ネル [Vapnik 95] と組み合わせて用いた .

$$
K_{d}^{\text {poly }}\left(T, T^{\prime}\right)=\left(1+K\left(T, T^{\prime}\right)\right)^{d}
$$

ここで, $d$ は多項式カーネルの次数である.人工データは 图 5 の 2 つの木構造を同時に含むときに正例となるよう に生成したため，多項式カーネルと組み合わせた場合に は $d=2$ のときに最も精度がよくなると予想される . 表 1 に 5 回の実験の平均の分類精度を示す. 太字で示した

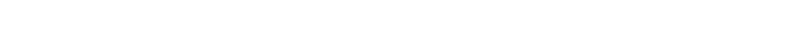
に，提案手法の分類精度は，ラベルの数だけを用いた場 合の結果をほぼ $20 \%$ 程度大きく上回っており，ラベル付 き順序木カーネルがデータに含まれる部分構造を認識で きていることがわかる．また，予想通り，多項式カーネ ルの次数は 2 であるときが最も精度が高くなっているこ とが分かる。

\section{$5 \cdot 2$ HTML 文書を用いた分類実験}

次に , 実際の HTML 文書をレイアウトなどの構造情 報に基づき分類する実験を行う．従来，テキスト分類の タスクは, 含まれる単語の種類を用いた特徵ベクトル表 現である'bag-of-words' 表現 [Salton 88, Joachim 98] を 用いるのが普通である．しかしながら，HTML 文書など の構造をもった文書は, タグを用いてレイアウトなどの 視覚的な情報を木構造として持っている.この実験では， HTML 文書のもつ木構造に基づき , HTML 文書の分類 を行うという実験を行う.

我々は , 2002 年における日本 IBM の Web サイト ${ }^{* 2}$ お

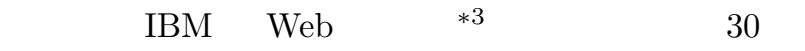
HTML ページを収集した .これらのページはお互いに

\footnotetext{
$* 1$ 正例は, 図 5 の 2 つの部分構造を含んだうえで, 残りの部 分をランダムに生成した

*2 http://www.ibm.com/jp/

$* 3$ http://www.ibm.com/
}

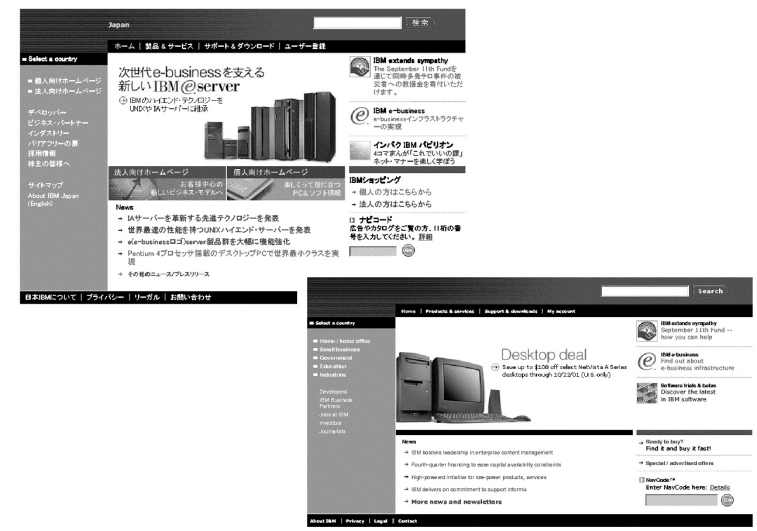

図 6 収集した HTML ページの例

非常に似ている (図 6) が, デザインのテンプレートや， デザイナーの違いがタグ構造の微妙な違い, すなわち， HTML の木構造に現われるであろうと考えられる .

この実験では, 構造情報にのみ注目しているため, テ キスト部分は削除し，タグのみを用いた ${ }^{* 4}$.

得られたラベル付き順序木は, 10〜1500 個のノードを 持ち (主に 200〜400 個)，90 種のタグが含まれていた .

この実験では, BoL カーネル, 基本のラベル付き順序 木カーネルに加え，構造の柔軟性を許すラベル付き順序

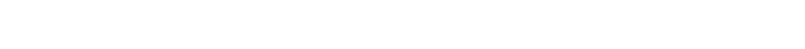
ネルを多項式カーネルと組み合わせて用いた . 表 2 に実 験結果を示す . 基本のラベル付き順序木カーネルが $\mathrm{BoL}$ カーネルに $20 \%$ の差をつけて, もっとも高い精度を出し ており，構造の違いをうまく捉えていることがわかる．

また, 基本のラベル付きカーネルが $d=4$ のときに, 構 造の柔軟性を許す場合には $d=3$ のときに最高精度であっ たことから, 分類には 3 個程度の, 多少の曖昧さをもった 部分構造が効いている可能性があると考えられる.

構造の柔軟性を許す場合は，基本の場合に比較してか えって精度か落ちているが, これは恐らく過度の柔軟性に より過学習を起こしているものと推測される ${ }^{* 5}$.このよう な問題を解決する方法としては, 部分構造の重み付けを行 つた畳み込みカーネル（あるいは周辺化カーネル [Tsuda 02]）を用いて，

$$
K\left(T, T^{\prime}\right)=\sum_{s \in S(T)} \sum_{s^{\prime} \in S\left(T^{\prime}\right)} w(s, T) w\left(s^{\prime}, T^{\prime}\right) K^{S}\left(s, s^{\prime}\right)
$$

のように部分構造の重み $w(s, T)$ を導入して , 複雑な部 分構造に対して重みを小さくするような拡張を行うこと が考えられるであろう .

\footnotetext{
*4 勿論この場合には, テキスト部分を用いれば文字コードの違 いからほぼ $100 \%$ の分類精度が得られるはずである

*5 たとえば [Kashima 02] などで, 構造の柔軟性が情報抽出タ スクにおいて有効であった結果が示されている。
} 
表 2 HTML 文書を用いた分類実験の結果 (leave-one-out クロ スバリデーションによって計測 .)

\begin{tabular}{cccc}
\hline$d$ & BoL カーネル & 木カーネル (基本) & 木カーネル $($ 柔軟 $)$ \\
\hline 1 & $41.7 \%$ & $63.3 \%$ & $61.7 \%$ \\
2 & $55.0 \%$ & $71.7 \%$ & $60.0 \%$ \\
3 & $\mathbf{5 8 . 3 \%}$ & $75.0 \%$ & $\mathbf{6 6 . 7 \%}$ \\
4 & $51.7 \%$ & $\mathbf{8 0 . 0 \%}$ & $60.0 \%$ \\
5 & $51.7 \%$ & $71.7 \%$ & $63.3 \%$ \\
\hline
\end{tabular}

\section{6. 関 連 研 究}

カーネル法を用いるほかにも，構造をもつデータを扱 う学習のアプローチがいくか存在する.

関係学習 [Mitchell 97] は, 述語論理で記述されたデー 夕を扱う一般的な手法である. 部分構造は，予め定義さ れたデータの構成要素の関係を組み合わせによって表現 され，属性として用いられる . 属性は , 分類に役立つもの が訓練の際に逐次的にに構成される。しかしながら，通 常，目的関数を最適化する仮説の探索はNP 困難となり， ヒューリスティックな探索手法が用いられる。

もう 1 つのアプローチとして ,データマイニングで用い られる構造データからの頻出パターン発見手法 [Inokuchi 00]に基づく方法が挙げられる.この方法は，データに頻 繁に現れる部分構造を列挙しておき，これらを属性とし て用いる.この方法では, クラス情報のないデータを利 用できるという利点があるが，パターン発見の問題は通 常 NP 困難な問題である . Kudo らは，マイニング手法 とブースティングを組み合わせることで, 有効な属性の みを発見する興味深い手法を提案している [Kudo 05] .

構造をもったデータに対するカーネル関数の設計方法 としては，いくつかの枠組みが提案されている*6.たと えば, 構造データの生成モデルが分かっているような場 合には，Fisher カーネル [Jaakkola 99] を用いることが 可能である . Fisher カーネルでは, 特徵ベクトルにおけ る各属性は, 生成モデルの尤度関数のパラメータについ ての勾配によって定義され，特徵ベクトルの次元はパラ メータ数に等しくなる.

本論文のように，生成モデルを仮定しない場合には，畳 み込みカーネル [Haussler 99] が一般的である .この枠 組みに基づき，樣々な構造を持ったデータに対する畳み 込みカーネルが提案されている.たとえば，Lodhi らは， 配列構造におけるすへてての部分列を部分構造として用い るようなカーネルを提案している [Lodhi 02] . また , 部 分構造を連続した部分列に限った場合には，接尾辞木を 用いて線形時間で高速にカーネルを計算する手法 [Leslie 02, Leslie 03] も提案されている.グラフ構造を持ったデー タに関しては,グラフ上のランダムウォークによって生成 される経路を部分構造とするようなカーネルが提案され ている [Kashima 03, Schölkopf 04, Gärtner 02, Suzuki

*6［Gärtner 03] に詳細なサーベイがある .
03] .

また , 2 つのアプローチの中間的アプローチとして , 生 成モデルによる部分構造の重み付けを用いながら，畳み 込みカーネルを計算するような, 周辺化カーネル [Tsuda 02, Kin 02] の枠組みも提案されている.

カーネル法では, 特徵空間での表現か暗黙的であるため に, 有効な部分構造を特定するのが困難になるという問題 があるが, パターン発見手法を援用することで重要な部分 構造を発見するというハイブリッド的アプローチ [Kudo 03, Suzuki 04] も提案されている.

\section{7. 結 論}

本論文では，木構造をもったデータに対するカーネル 関数の設計について論じた . まず, 畳み込みカーネルの 枠組みにおいてラベル付き順序木に対して任意の部分グ ラフを部分構造として用いた場合の，効率の良いカーネ ル計算のアルゴリズムを提案し, 曖昧なラベルや構造を 取り込むような拡張を行った .さらに,より一般的な木構 造として，順序のないラベル付き根付き木に対するカー ネルを考えた場合には, カーネルの計算が\#P-完全問題 であることを示した .

今後の課題としては, まず 5 章の最後で述べたよう な, 部分構造の重み付けを考慮することか挙げられるで あろう.これには 2 つのアプローチが考えられる. $1 つ$ は 6 章で述べた, 陽に特徵選択を行うアプローチ $[$ Kudo 03, Suzuki 04]であり，もう 1つは特徵選択をも暗黙のう ちに行うというアプローチであろう．暗黙の特徵空間にお ける特徵選択法としてはカーネル主成分分析 [Schölkopf 88] などが挙げられるが, 畳み込みカーネルの部分構造 の重み付けパラメータを予め学習しておくことも暗黙の 特徵選択の効果があると考えられ，これら各種の特徵選 択法の比較を行うことも 1 つの課題であろう.

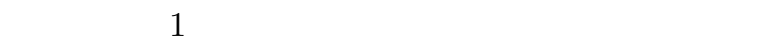
ルの設計が考えられる . 動的計画法に基づくカーネル計 算アルゴリズムは基本的に 2 つの構造の大きさの積程度 の計算時間が溎かってしまうが，よりスケーラビリティ が重要な場合では，線形時間に近い速さで計算できるよ うな木カーネルか望まれる.ラベルの曖昧さを許さず, 部 分構造を根から葉へ向かうパスの集合などに限定し，接 尾辞木 [Leslie 02] を用いるなど, 表現力と計算速度のバ ランスをとるための工夫が必要であろう .

\section{$\diamond$ 参 考 文 献 $\diamond$}

[Collins 02] Collins, M. and Duffy, N.: Convolution Kernels for Natural Language, in Advances in Neural Information Processing Systems 14, Cambridge, MA (2002), MIT Press

[Durbin 98] Durbin, R., Eddy, S., Krogh, A., and Mitchison, G.: Biological Sequence Analysis: Probabilistic Models of Proteins and Nucleic Acids, Cambridge University Press (1998) 
[Freund 99] Freund, Y. and Shapire, R.: Large Margin Classification using the Perceptron Algorithm, Machine Learning, Vol. 37, No. 3, pp. 277-296 (1999)

[Gärtner 02] Gärtner, T.: Exponential and Geometric Kernels for Graphs, in NIPS*02 Workshop on Unreal Data: Principles of Modeling Nonvectorial Data (2002), Available from http://mlg.anu.edu.au/unrealdata/

[Gärtner 03] Gärtner, T.: A Survey of Kernels for Structured Data, SIGKDD Explorations, Vol. 5, No. 1, pp. S268-S275 (2003)

[Haussler 99] Haussler, D.: Convolution Kernels on Discrete Structures, Technical Report UCSC-CRL-99-10, University of California in Santa Cruz (1999)

[Inokuchi 00] Inokuchi, A., Washio, T., and Motoda, H.: An Apriori-Based Algorithm for Mining Frequent Substructures from Graph Data, in The Fourth European Conference on Principles and Practice of Knowledge Discovery in Databases, pp. 13-23 (2000)

[Jaakkola 99] Jaakkola, T. S. and Haussler, D.: Exploiting generative models in discriminative classifiers, in Kearns, M. S., Solla, S. A., and Cohn, D. A. eds., Advances in Neural Information Processing Systems 11, Cambridge, MA (1999), MIT Press

[Joachim 98] Joachim, T.: Text categorization with support vector machines, in Proceedings of the tenth European Conference on Machine Learning (1998)

[Kashima 02] Kashima, H. and Koyanagi, T.: Kernels for Semi-Structured Date, in Proceedings of the Nineteenth International Conference on Machine Learning, pp. 291-298, San Francisco, CA (2002), Morgan Kaufmann

[Kashima 03] Kashima, H., Tsuda, K., and Inokuchi, A.: Marginalized Kernels between Labeled Graphs, in Proceedings of the Twentieth International Conference on Machine Learning, San Francisco, CA (2003), Morgan Kaufmann

[Kin 02] Kin, T., Tsuda, K., and Asai, K.: Marginalized Kernels for RNA Sequence Data Analysis, in Genome Informatics 13, pp. 112-122 (2002)

[Kudo 03] Kudo, T. and Matsumoto, Y.: Fast Methods for Kernel-based Text Analysis, in Proceedings of the 41st Annual Meeting of the Association for Computational Linguistics (2003)

[Kudo 05] Kudo, T., Maeda, E., and Matsumoto, Y.: An Application of Boosting to Graph Classifications, in Advances in Neural Information Processing Systems (2005)

[Leslie 02] Leslie, C., Eskin, E., and Noble, W. S.: The spectrum kernel: A string kernel for SVM protein classification, in Altman, R. B., Dunker, A. K., Hunter, L., Lauerdale, K., and Klein, T. E. eds., Proceedings of the Pacific Symposium on Biocomputing, pp. 566-575, World Scientific (2002)

[Leslie 03] Leslie, C., Eskin, E., Weston, J., and Noble, W.: Mismatch String Kernels for SVM Protein Classification, in Becker, S., Thrun, S., and Obermayer, K. eds., Advances in Neural Information Processing Systems 15, Cambridge, MA (2003), MIT Press

[Lodhi 02] Lodhi, H., Saunders, C., Shawe-Taylor, J., Cristianini, N., and Watkins, C.: Text classification using String Kernels, Journal of Machine Learning Research, Vol. 2, pp. 419-444 (2002)

[Manning 99] Manning, C. D. and Schütze, H.: Foundations of Statistical Natural Language Processing, The MIT Press, Cambridge, MA (1999)

[Mitchell 97] Mitchell, T.: Machine Learning, McGraw-Hill (1997)

[Salton 88] Salton, G. and Buckley, C.: Term weighting approaches in automatic text retrieval, Information Processing and Management, Vol. 24, No. 5, pp. 513-523 (1988)

[Schölkopf 88] Schölkopf, B., Smola, A., and Müller, K.-R.: Nonlinear component analysis as a kernel eigenvalue problem, Neural Computation, Vol. 10, pp. 1299-1319 (1988)

[Schölkopf 04] Schölkopf, B., Tsuda, K., and Vert, J.-P. eds.: Kernel Methods in Bioinformatics, MIT Press, Cambridge,
MA (2004)

[Shawe-Taylor 04] Shawe-Taylor, J. and Cristianini, N.: Kernel Methods for Pattern Analysis, Cambridge University Press (2004)

[Suzuki 03] Suzuki, J., Hirao, T., Sasaki, Y., and Maeda, E.: Hierarchical Directed Acyclic Graph Kernel: Methods for Structured Natural Language Data, in Proceedings of the Fouty-first Annual Meeting of Association for Computational Linguistics (2003)

[Suzuki 04] Suzuki, J., Isozaki, H., and Maeda, E.: Convolution Kernels with Feature Selection for Natural Language Processing Tasks, in Proceedings of the 42nd Annual Meeting of the Association for Computational Linguistics (2004)

[Tsuda 02] Tsuda, K., Kin, T., and Asai, K.: Marginalized Kernels for Biological Sequences, Bioinformatics, Vol. 18, No. Suppl. 1, pp. S268-S275 (2002)

[Vadhan 01] Vadhan, S. P.: The Complexity of Counting in Sparse, Regular, and Planar Graphs, SIAM Journal on Computing, Vol. 31, No. 2, pp. 398-427 (2001)

[Valiant 79a] Valiant, L. G.: The Complexity of Computing the Permanent, Theoretical Computer Science, Vol. 8, pp. 189-201 (1979)

[Valiant 79b] Valiant, L. G.: The Complexity of Enumeration and Reliability Problems, SIAM Journal on Computing, Vol. 8, No. 3, pp. 410-421 (1979)

[Vapnik 95] Vapnik, V.: The Nature of Statistical Learning Theory, Springer Verlag (1995)

\section{〔担当委員 : 伊藤 公人〕}

2005 年 6 月 30 日 受理

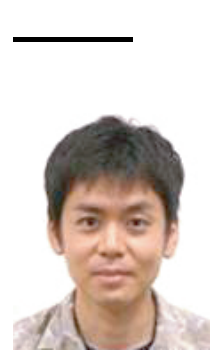

\section{者 紹 介}

\section{鹿島 久嗣 (正会員)}

1999 年 3 月京都大学工学研究科応用システム科学専攻修 士課程修了. 同年 4 月日本アイ・ビー・エム (株) 入社 東京基整研究所に所属.機械学習, データマイニングの研 究に従事

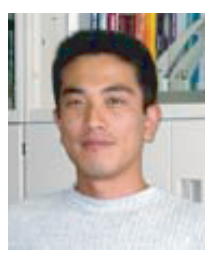

坂本 比呂志(正会員)

1996 年 3 月九州大学大学院システム情報科学研究科情報 理学専攻修士課程修了. 同年 4 月日本学術振興会特別研究 員 (DC1). 1998 年 12 月同研究科博士課程修了. 1999 年 1 月九州大学大学院システム情報科学研究科情報理学專 攻助手. 2003 年 8 月から九州工業大学情報工学部助教授 現在に至る、機械学習と計算量理論, Web 上のテキスト データからの知識獲得, データ圧縮およひ効率的なデータ 構造の研究に従事. 博士 (理学) .

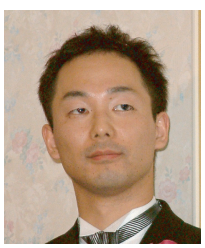

小柳 光生

1999 年 3 月筑波大学理工学研究科修士課程修了.同年 4 月日本アイ・ビー・エム (株) 入社. 東京基礎研究所に所 属.XML , サーバサイドアプリケーション基盤技術, 業 務プロセスアプリケーションの研究に従事 . 